\title{
MYOCARDIAL REACTION TO ENERGY DRINKS IN A GUINE A PIG: STRUCTURAL CHANGES
}

\author{
Aldona Gružienè ${ }^{1}$, Lina Malcienè ${ }^{1}$, Sigita Kerziené ${ }^{2}$, Darijus Skaudickas ${ }^{3}$, \\ Gintautas Vaitiekaitis ${ }^{2}$, Greta Pečiulyté ${ }^{3}$ \\ ${ }^{1}$ Institute of Physiology and Pharmacology, Lithuanian University of Health Sciences, Kaunas, Lithuania, \\ ${ }^{2}$ Department of Mathematics and Biophysics, Lithuanian University of Health Sciences, Kaunas, Lithuania, \\ 3Department of Urology, Lithuanian University of Health Sciences, Kaunas, Lithuania
}

Key words: energy drinks, myocardium collagen network, remodeling, fibrillar collagen, morphometric analysis.

\begin{abstract}
Summary
The aim of this study was to evaluate myocardial changes in a short-haired guinea pig (Cavia porcellus L) after everyday use of energy drinks for 60 days. The experiments were carried out on 11 male guinea pigs, age of 2 months, with a mean weight of $220 \pm 0.2 \mathrm{~g}$. The guinea pigs were randomly grouped into a control group of 5 guinea pigs and experimental group of 6. Experimental group guinea pigs were orally administered energy drinks $4 \mathrm{ml}$ per day as a single oral dose. After the 60 days experiment, the quantitatively evaluated structures of myocardial interstitial collagen in the left ventricle using automated image analysis system, which was connected to Olympus BXx51 microscope. Assessment was performed with Image-Pro Plus 5.1 analysis system. We calculated volume and perimeter of the interstitial fibrillar collagen in the left ventricular myocardium, the number of separate fibers in the field of view were counted. In total, there was evaluated 100 fields of view in the control group and 120 fields of view in the experimental group. Statistical analysis was performed using statistical package SPSS Statistics 20 and Microsoft Excel. We used bifactorial analysis of variance (ANOVA) to compare histomorphometric parameters between the two groups.

We assessed that the difference between parameters was up to $1 \%$ and the individual specific effect was counting for $50 \%(\mathrm{p}<0.05)$. Variation of the features was much larger within the experimental group, when compared to the control group. Maximum average values of the fibrillar collagen volume, perimeter
\end{abstract}

and the number of separate fibers in the field of view were 1.2 times larger in the experimental group than in the control group.

Repeated energy drink consumption acts as external factor stimulating adaptive remodeling processes. Quantative structural changes of fibrillar collagen in left ventricle of experimental group animals are reaction to a stress factor. Unbalanced changes of fibrillar collagen may determine inadequate remodeling and become a reason for pathogenesis.

\section{Introduction}

Energy drinks have gained worldwide popularity, especially among the youth, and their adoration is increasing as time progresses. This is illustrated clearly through a steady increase in industry sales globally and poised for further growth. The strong cultural consumption is a matter of great concern in developed countries, as the intake of these energy drinks leads to various outcomes and its heavy consumption has a significant detrimental effect on health [1-3]. Furthermore, numerous studies done recently have presented data indicating an epigenetic inheritance factor. This is synonymous with evidence also showing that elements of a diet may change the activity of genes expressed in both animals and humans. Epigenetic systems participate from protein synthesis and DNA replication before cell division to DNA repair. Through this direct influence, a person may alter his/ her genetic code's activity depending on lifestyle and living conditions [4-9].

The energy drink industry encompasses a broad spectrum of products ranging through their respective ingredients. However, all energy drinks include in their formulation a similar group of essential ingredients including caffeine, guaranine, carnitine, ginkgo (Ginkgo biloba L.), glucuronolactone, ginseng, inositol, taurine and B vitamins. The dosage quantity for a standard energy drink container is $150-300 \mathrm{ml}$. 
This equates to $48-96 \mathrm{mg}$ of caffeine in a single dosage (32 $\mathrm{mg} / 100 \mathrm{ml}$ ). The manufacturers indicate on the packaging the amount of caffeine directly incorporated within each drink. However, they fail to acknowledge the additional quantities of caffeine present within the other ingredients. Three other key ingredients found within a standard energy drink, Guarana (Paullinia cupana L.), Cacao (Theobroma cacao L.) and Yerba Mate (Ilex paraguariensis L.) extracts, all contain caffeine [10-12]. This indirect addition of caffeine results in higher doses per package than it is indicated on the nutritional label. The consequences of continuous caffeine intake are still not well-known, and there is scant research on the interaction energy drink ingredients will have on a living organism [13].

Researchers have performed numerous studies evaluating psychological and physiological effects of caffeine on living organisms. These explored the changes in hemodynamic and electrocardiogram parameters. After the consumption of an energy drink, activation of the sympathetic and central nervous system arouses positive chronotropic and inotropic effects in the heart, subsequently increasing blood pressure. That is to say functional changes have occurred, showing the activity of the heart has intensified. Similarly, cardiac activity is intensified to address a higher workload following a period of strenuous physical exercise. Studies show that repeated workloads, which require great stamina, eventually determine histological changes in the myocardium [14-15]. Frustaci and colleagues reported a study in which they claimed that $17 \%$ of athletes have fibrillar collagen changes in the myocardium (fibrosis). Subsequently, an inflammation of the myocardium and structural remodeling of collagen fibers results in the formation of proarrhythmic substrate and dysfunction of the myocardium [16]. Numerous cases have been recorded where expanded collagen networks were present in cases of a pressure overload (arterial hypertension), aortic valve insufficiency and other heart diseases $[17,18]$. Further evidence backing the changes in the myocardial interstitium, namely its fibrillar collagen, continually support the degradation of cardiac mechanism, however experimental data from energy drink influence is minimal.

The aim of the study. To evaluate myocardial and quantitative structural changes in the main component of the interstitial intercellular matrix - fibrillar collagen - among short-haired guinea pigs following daily consumption of energy drinks over a period of 60 days.

\section{Materials and Methods}

The experiments were carried out on 11 short-haired male guinea pigs (Cavia porcellus L.) (age 60 days), with mean weight of $220 \pm 0.2 \mathrm{~g}$.
6 short-haired guinea pigs were orally administered energy drink on a daily basis, once a day, for 60 days. The energy drink ( $4 \mathrm{ml}$ per day as a single oral dose) was given by squirting it into the guinea pig's mouth through a toothless side of the jaw and letting the guinea pig to swallow the drink. Daily dose of the energy drink was calculated in accordance with the maximum recommended daily caffeine intake for a human (a safe daily dose of caffeine is up to 340 mg per day according to the National Food and Veterinary Risk Assessment Institute in Lithuania).

Another 5 short-haired guinea pigs were included in a control group for direct comparison. The guinea pigs were euthanized using Dolethal which was injected in the abdominal cavity. The whole heart was fixed in $10 \%$ formalin and embedded in paraffin wax. Histological sections (histotopograms) were $4 \mu \mathrm{m}$ thick and stained using hematoxylin and eosin, Picro-Mallory Trichrome and Picro-Sirius Red staining techniques. Structures of interstitial collagen network were evaluated using an automated image analysis system which was connected to an Olympus BX51 microscope.

We estimated parameters of the fibrillar collagen network in the myocardium of the left ventricle by averaging the size across 20 fields of view (the field of view is at 400-times magnification, the size of the field of view is $143559 \mu^{2}$ ) for every short-haired guinea pig. We evaluated the histotopograms by calculating both the volume and perimeter of the interstitial fibrillar collagen that was in the left ventricular myocardium. Furthermore, we counted the number of separate fibers in the field of view. The calculations were made using an Image-Pro Plus 5.1 analysis system. We evaluated the short-haired guinea pigs' collagen fibril network parameters by analyzing 100 fields of view in the control group and 120 fields of view in the experimental group altogether.

\section{Statistical analysis}

Statistical analysis was performed using the software package IBM SPSS Statistics 20.0 (SPSS Inc., Chicago, IL, USA) and the spreadsheet application MS Excel 2007. Differences in histomorphometric parameters between two groups were compared using the two-factor and nested design analysis of variance (ANOVA), evaluating the variances of morphometric parameters within a group and within every guinea pig separately. The difference is statistically significant only if the probability of error is less than 0.05 $(p<0.05)$. Correlations among the parameters were obtained using a correlation and regression analysis.

\section{Results}

Short-haired guinea pigs that were included in the control (K) group and experimental $(\mathrm{J})$ group gained $176.3 \pm 0.1 \mathrm{~g}$ 
weight (body mass) on the average during 60 days period. Weights of the hearts (weighed after the performance of euthanasia) were similar in both groups: $1.4 \pm 0.2 \mathrm{~g}$ average in the control group and $1.3 \pm 0.2 \mathrm{~g}$ average in the experimental group.

Using the formula defined as weight of the heart divided by body mass (weight of the heart/body mass), we obtained that the hearts were not hypertrophied in either group. Average of the control group: weight of the heart/body mass = 0.0041 . Average of the experimental group: weight of the heart/body mass $=0.0038$.

Even eminently precise calculations of these parameters do not describe the existing cardiac changes in an explicit way. Moreover, there may be alternate changes identified after a cardiac event (a stroke, pressure and/or volume overload, etc.) which systemically does not change the mass and volume of the heart or ventricle.

We analyzed parameters of the left ventricular collagen fibril network within the experimental group (fibrillar collagen's volume, perimeter and the number of separate fibers in the field of view) and compared it with the parameters within the control group. There were small differences (up to 1\%) among the groups which were not statistically significant. In both groups, correlative relationships between the same features were very strong (ranged from 0.79 to $0.97, \mathrm{p}<$ 0.001 ), but they did not differ statistically significantly. We obtained that the individual effect is very large (counting for about 50\%) (see Tab. 1).

Within each group, the parameters of the guinea pigs fibrillar collagen network differed from each other statistically significantly $(\mathrm{p}<0.05)$.

We obtained that the averages did not differ within each

Table 1. The researched factors effect $\left(\eta^{2}\right.$, pct.) on the parameters of the fibrillar collagen network.

\begin{tabular}{|c|c|c|c|c|}
\hline & & $\begin{array}{c}\text { The num- } \\
\text { ber of fiber } \\
\text { bundles }\end{array}$ & $\begin{array}{c}\text { Volume of } \\
\text { collagen } \mathrm{x} \\
100 \%\end{array}$ & $\begin{array}{c}\text { Perime- } \\
\text { ter } \mathrm{mm} / \\
\mathrm{mm}^{2}\end{array}$ \\
\hline \multirow{2}{*}{$\begin{array}{l}\text { Effect of a } \\
\text { factor } \eta^{2} \text {, } \\
\text { pct. }\end{array}$} & Group's & 0.001 & 0.007 & 0.005 \\
\hline & $\begin{array}{l}\text { Individual's } \\
\text { (Guinea pig's) }\end{array}$ & $50,6^{* * *}$ & $47,2 * * *$ & $55,5 * * *$ \\
\hline
\end{tabular}

Table 2. The descriptive statistics of the researched parameters within the compared groups.

$*_{-} p<0,05 ; * *_{-} p<0,01 ; * * *_{-} p<0,001$ (of differences between max and min in the groups)

\begin{tabular}{|l|c|c|c|}
\cline { 2 - 4 } \multicolumn{1}{c|}{} & $\begin{array}{c}\text { The number of } \\
\text { fiber bundles }\end{array}$ & $\begin{array}{c}\text { Volume of col- } \\
\text { lagen } \times 100 \%\end{array}$ & $\begin{array}{c}\text { Perimeter } \mathrm{mm} / \\
\mathrm{mm}^{2}\end{array}$ \\
\hline K group & $1587,2 \pm 55,76$ & $6,49 \pm 0,25$ & $15223,3 \pm 537,48$ \\
\hline J group & $1619,2 \pm 67,81$ & $6,85 \pm 0,28$ & $15806,4 \pm 637,91$ \\
\hline
\end{tabular}

group (see Tab. 2), but variation of the features was much greater (more than 10\%) within the experimental group (see Tab. 3). The variation of all the features differed among the groups was statistically significantly $(\mathrm{p}<0.05)$ (see Fig. 1$)$.

We compared the maximum average values of the parameters between the control group and the experimental group and we found that the volume (pct.), the number of collagen network bundles and the perimeter of the fibers were 1.2 times greater in the experimental group when compared to the control group, which was statistically significant. The minimum average values of the parameters were similar among the groups.

In evaluating the correlation between morphometric parameters, we identified certain characteristics across test subjects. After the performance of a regression analysis, we identified that a direct linear regression relationship best described the dependence between the features in both groups (all the correlations within both groups were statistically significant when $\mathrm{p}<0.001)$. Left ventricular collagen network volume (pct.) and the number of bundles (K group - $\mathrm{r}=0.79$; $\mathrm{J}$ group - $\mathrm{r}=0.86$ ) correlated between both groups the weakest. Left ventricular collagen network perimeter and the number of bundles correlated the strongest (in both groups $\mathrm{r}=0.97$ ).

The results of the regression analysis let us consider that if the number of fiber bundles increased on average by 1000 , the volume of collagen averagely increases by $3.6 \%$ (see Fig. 2 ); if the volume of collagen increased by $1 \%$, the perimeter on average would increase by $1906 \mathrm{~mm} / \mathrm{mm}^{2}$ in K group and by $2112 \mathrm{~mm} / \mathrm{mm}^{2}$ in J group (see Fig. 3); if the number of fiber bundles increased by 1000 , the perimeter average would increase by $9331 \mathrm{~mm} / \mathrm{mm}^{2}$ in K group and by 9129 $\mathrm{mm} / \mathrm{mm}^{2}$ in J group (see Fig. 4).

\section{Discussion}

The cardiac muscle - myocardium - consists of cardiomyocytes that are bound together and supported by a con-

Table 3. Minimum and maximum average values and variance coefficient of the researched parameter and variation coefficient (pct.).

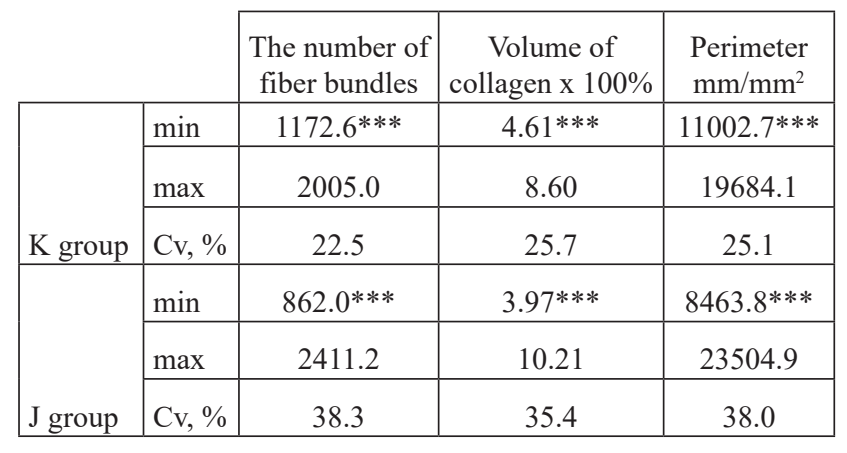


nective tissue network which is composed of collagen fibers. Myocardial collagen fibers are consisted of type I, type II and type V fibrillar collagen. These types of collagen are synthesized by fibroblasts and account for about $90 \%$ of all the collagen within the heart [19-21]. Interstitial collagen networks support the architecture and the arrangement of the cardiomyocytes during the cardiac cycle and the improves force transferred to the ventricular chambers. When the cardiomyocytes contract, the energy accumulated in outstretched collagen fibers partakes in myocardial relaxation and filling of the ventricular chambers [22]. Renewal of the collagen network proceeds constantly. At usual conditions, only a small part of newly synthetized procollagen is required for the renewal of the collagen network, so the major part of it is rapidly decomposed [23].

The collagen quantity within the intercellular matrix (IM), is maintained by the renin-angiotensin-aldosterone system (RAAS). The regulation of the IM structure, is controlled by both circulating angiotensin II and amounts found within the myocardium, endocardium and right atrium [24-25]. It is known that angiotensin II stimulates synthesis of DNA and collagen in the culture of human fibroblasts. Angiotensin II molecules bind to AT receptors which are present in fibroblast membrane and through this, activate factors which play the main role in the expression of genes responsible for IM proteins [26]. Desoxycorticosterone also stimulates collagen synthesis in the culture of fibroblasts. It is understood that a longterm action of angiotensin II determines the increase in the collagen concentration (development of fibrosis)

Increased sympathetic nervous system (SNS) activity is very significant in the promotion of structural remodeling of the collagen network [28]. This is due to a SNS induced activation of cytokine release [29-31]. Chronic adrenergic stimulation increases activity of the RAAS and subsequently determines cardiomyocytes hypertrophy and programmed cell death [32]. Despite these factors, myocardial remodeling is determined by oxidative stress $[33,34]$.

An abundance of collagen in the heart occurs when its synthesis exceeds its deposition. It may be because of the increasing collagen synthesis, decreasing collagen deposition or a combination of the two. This process may appear with or without cardiomyocytes hypertrophy [35-37]. When the number of fibrillary collagen fibers increases, myocardial elasticity decreases. Proportions of the fibrillary collagen may vary across an organism as it ages, it's various pathological conditions or even if it consistently performs physical exercise at a high output,

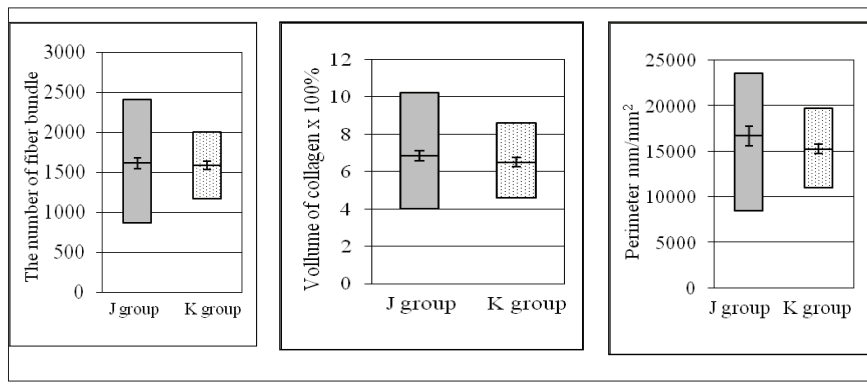

Figure 1. The number of collagen network bundles, volume (pct.), perimeter (amplitude of variation, average, standard error).

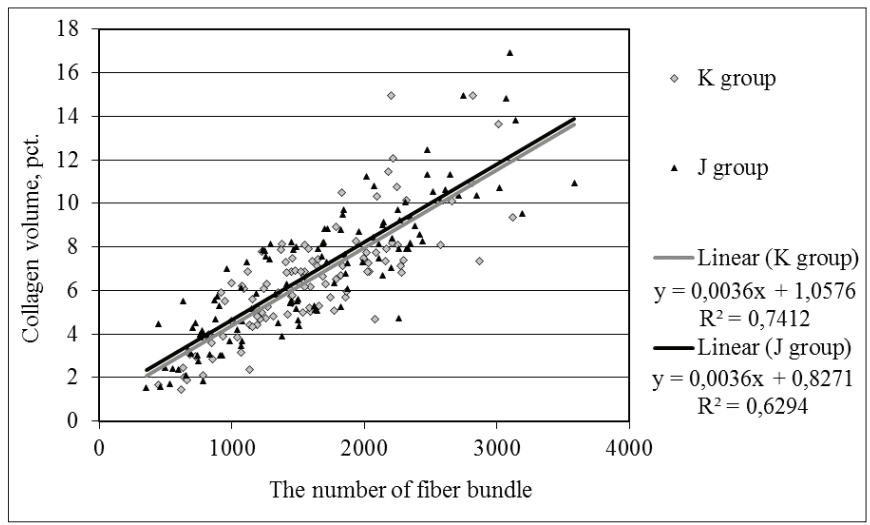

Figure 2. The correlation between the left ventricular collagen volume and the number of fiber bundles.

such as a professional athlete [38-40].

In our study we wanted to find out if energy drinks may become an episodic external stimuli that provokes the remodeling of the collagen network in a consumer's myocardium. We tested this through daily administration in guinea pigs consuming a controlled, measured quantity. That is because caffeine and other bioactive substances which are included in an energy drink, affect a consumer's body diversely even without exceeding manufacturer's recommended dosage (a recommended dosage of caffeine is up to $300 \mathrm{mg}$ caffeine per day, keeping in mind that such an amount is usually found in three cans of energy drink).

The most frequent consequences are related with cardiac contractility and function of the nervous system. It is well established that after consumption of energy drinks blood pressure increases by 5 - 10 measure units, the heart beats $5-7$ times more frequent than usual $[41,42]$, there may also be an prolongation of the QT interval, and cardiac arrhythmia. The sodium quantity in a regular sized vessel of an energy drink exceeds three times the daily recommended dose and according to USA scientists, may cause heart attack $[43,44]$.

Caffeine is an analeptic substance included in a group of 


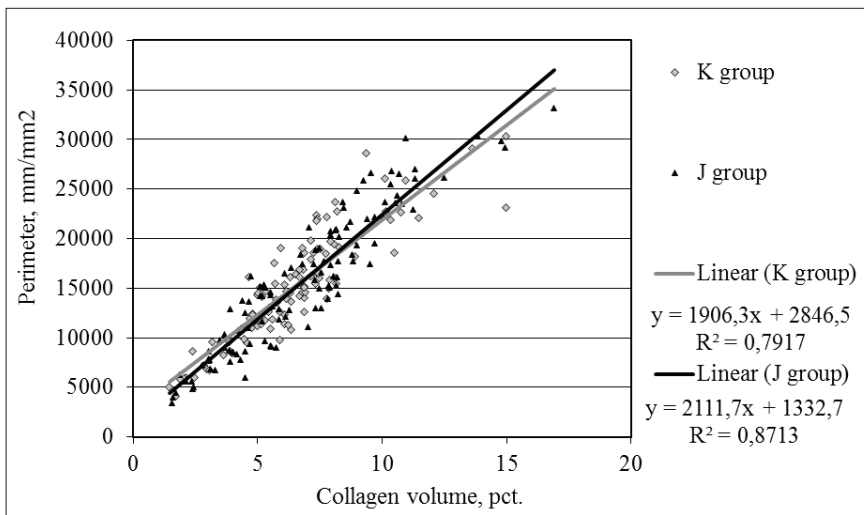

Figure 3. The correlation between the left ventricular collagen volume and the perimeter.

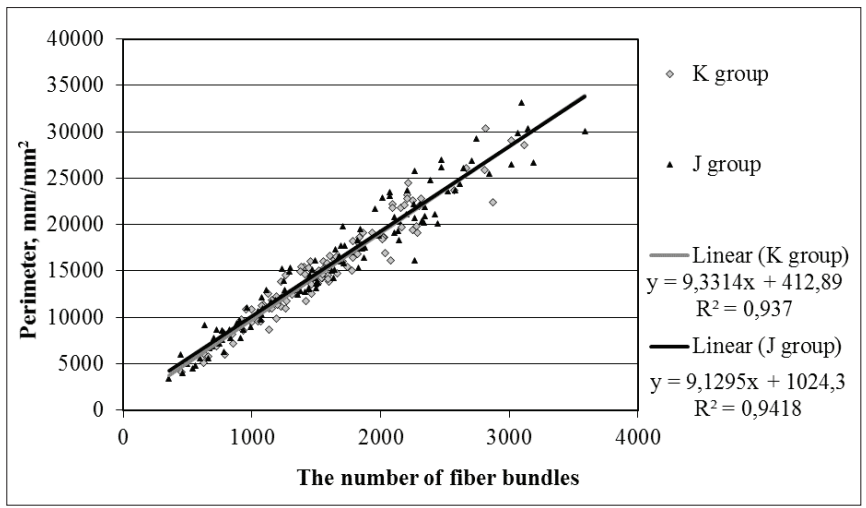

Figure 4. The correlation between left ventricular collagen perimeter and the number of fiber bundles.

$*_{-} p<0,05 ; * *-p<0,01 ; * * *-p<0,001$

methylxanthines therefore it increases an intracellular concentration of calcium ions and cyclic adenosine monophosphate (cAMP). Consequently, after an energy drink intake it may produce positive cardiac inotropic and chronotropic effects [45]. Australian scientists claimed that if the concentration of glucuronolactone, which is included in the energy drinks, exceeds a safe upper daily limit, it may cause a heart attack. Furthermore, they found out that one can of the energy drink cause the contraction of blood vessels [46,47]. The caffeine and other bioactive substances present have an influence on the adrenal glands causing the release of epinephrine, stimulation of sympathetic and central nervous systems. The bioactive substances included in the energy drinks not only increase the total concentration of caffeine, but also potentially extend the half-life of the caffeine [10-12]. Therefore, the energy drinks indirectly affect the myocardium and through many other physiological processes they impact on the heart's role as a mechanical pump. We can therefore assume that the ingredients included in the formulation of the energy drinks may activate some factors (mediators) of the remodeling process, for example, neurohumoral factors.

After every energy drink consumed, the activity of the heart is intensified: the heart contracts more frequent, the force of the contraction augments, arterial blood pressure increases. It emaciates the heart as the heart needs to overcome arterial résistance. Because of this reason the heart is continuously burdened, it must adjust to the new conditions and maintain adequate activity.

Our study showed that there appeared to be slender quantitative structural changes in the fibrillary collagen in the left ventricular myocardium of the guinea pigs which were included in the experimental group and had been in taking the energy drinks on the daily basis for 60 days. The variation of features is more than $10 \%$ greater within the experimental group, which may be explained by diverse responses that are dependent on individual's physiological characteristics (genetic variability). The parameters measured within the experimental group (the number of separate fibers, perimeter and volume (pct.) of the collagen) were 1.2 times larger than within the control group. The remodeling of the fibrillary collagen network in the left ventricle of the guinea pigs from the experimental group is associated with consumption of the energy drinks and most likely is a physiological response to efficiently maintain the force required to fulfill the cardiac load. The augmentation in the collagen fibers volume (pct.) may also be associated with changes in hemodynamic load and an increase in myocardial contraction force. Similar processes are presented in elderly people - collagen fibers become more dense and thicker [48]. When the number of collagen fibers increases, the myocardium becomes less elastic, for example, an increase by 2 - 3 times causes difficulty in the relaxation of the left ventricle. The increased number of collagen fibers may have a negative effect on the electrical stability [49]. Thus, gradual compensation for function of the ventricles may switch to decompensation due to developed pathological issues.

Norepinephrine, angiotensin II, aldosterone, peptide growth factors, free oxygen radicals and cytokines are causative factors (mediators) of remodeling and blastocyst activity. The results of our study showed there is a slender remodeling of the collagen network among the guinea pigs, which had been consuming the energy drinks daily for 60 days. Every time the guinea pigs consumed the energy drink, it became an episodic stimuli for remodeling. The remodeling of the left ventricular collagen network is adjusted to cardiac load and the remodeling of the fibrillary collagen has an impact on the heart 
activity. Therefore, there is a probability that a long-term consumption of the energy drinks may be associated with one or several known effects brought by the mediators that are responsible for the collagen remodeling and it may be associated with the untoward effects brought by unidentified factors (genetic, epigenetic). Structural remodeling of the heart collagen is an important precursor of cardiovascular diseases [50-54].

\section{Conclusion}

The consumption of energy drinks engenders functional changes in an individual organism. Among the guinea pigs tested, these repeated long-term changes determined slender quantitative structural alterations in the left ventricular fibrillary collagen and were associated with an untoward effect of the remodeling factors. The long-term remodeling of the collagen fibers may cause morphological changes in the myocardium, developing a foundation for deteriorative heart function and ultimately a precursor for further cardiovascular disease.

\section{References}

1. Malinauskas BM, Aeby VG, Overton, RF, Carpenter-Aeby T and Barber-Heidal K. A survey of energy drink consumption patterns among college students. Nutrition Journal 2007; 6:35. https://doi.org/10.1186/1475-2891-6-35

2 Reissig CJ, Strain EC, Griffiths RR. Caffeinated energy drinks - a growing problem. Drug and Alcohol Dependence 2009; 99: $1-10$. https://doi.org/10.1016/j.drugalcdep.2008.08.001

3. Kopacz A, Wawrzyniak A, Hamułka J, Górnicka M. Evaluation of energy drink intake in selected student groups. Roczniki Panstwowego Zakladu Higieny 2013; 64:1: 49-53.

4. Velazquez CE, Poulos NS, Latimer LA, Pasch KE, Velazguez CE. et al. Associations between energy drink consumption and alcohol use behaviors among college students: Journal Drug and Alcohol Dependence 2012; 123: 167-172. https://doi.org/10.1016/j.drugalcdep.2011.11.006

5. Pellegrini ML, Argibay P, Gomez DE. Dietary factors, genetic and epigenetic influences in colorectal cancer. Experimental and Therapeutic Medicine 2010; 241-250.

https://doi.org/10.3892/etm_00000038

6. Pomeranz JL, Munsell ChR and Harris JL. Energy drinks: An emerging public health hazard for youth. Journal of Public Health Policy 2013; 34: 254-271. https://doi.org/10.1057/jphp.2013.6

7. Trerotola M, Relli V, Simeone P, Alberti S. Epigenetic inheritance and the missing heritability. Human Genomics 2015; 9:17. https://doi.org/10.1186/s40246-015-0041-3

8. Kubota T, Miyake K and Hirasawa T. Epigenetic understanding of gene-environment interactions in psychiatric disorders: a new concept of clinical genetics. Clinical Epigenetics 2012; 4:1. https://doi.org/10.1186/1868-7083-4-1

9. Jaenisch R. Bird A. Epigenetics regulation of gene expression: how the genome integrates intrinsic and environmental signals. J Nature genetics 2003; 245-254.

https://doi.org/10.1038/ng1089

10. Cannon ME, Cooke C, McCarthy JS. Caffeine-induced cardiac arrhythmia: an unrecognized danger of health food products. Med J Aust 2001; 174 (10): 520 -521.

11. Ashihara H, Sano H, Crozier A. Caffeine and related purine alkaloids: biosynthesis, catabolism, function and genetic engineering, Phytochemistry 2008; 69 (4): 841-56. https://doi.org/10.1016/j.phytochem.2007.10.029

12. Kennedy DO, Haskell CF, Robertson B, Reay J, BrewsterMaund C, Luedemann J, Maggini S, Ruf M, Zangara A, Scholey $\mathrm{AB}$. Improved cognitive performance and mental fatigue following a multivitamin and mineral supplement with added Guarana (Paullinia cupana). Appetite 2008; 50 (2-3): 506-513. https://doi.org/10.1016/j.appet.2007.10.007

13. Aguilar F, Charrondiere U.R, Dusemund B. et al. The use of taurine and D-glucurono-gamma-lactone as constituents of the so-called "energy drinks". Pharmacotherapy 2012; 46 (2): 192-9.

14. Mihl C, Dassen WRM, Kuipers H. Cardiac remodelling: concentric versus eccentric hypertrophy in strength and endurance athletes. Neth Heart J 2008; 16(4): 129-133. https://doi.org/10.1007/BF03086131

15. La Gerche A, Burns AT, Mooney DJ, Inder WJ, Taylor AJ, Bogaert J, MacIsaac AI, Heidbuchel H, Prior DL. Exerciseinduced right ventricular dysfunction and structural remodelling in endurance athletes. European Heart Journal 2012; 33 : 998-1006.

https://doi.org/10.1093/eurheartj/ehr397

16. Bishop JE, Lindahl G. Regulation of cardiovascular collagen synthesis by mechanical load. Cardiovasc Res 1999; 42(1): 27-44.

https://doi.org/10.1016/S0008-6363(99)00021-8

17. Diez J, Lopez B, Gonzalez A, Querejeta R. Clinical aspects of hypertensive myocardial fibrosis. Curr Opin Cardiol 2001; 16: 328-35.

https://doi.org/10.1097/00001573-200111000-00003

18. Weber KT. A role for de novo angiotensin II generation. Circulation, 1997; 96: 4065-82.

https://doi.org/10.1161/01.CIR.96.11.4065

19. Bishop JE, Laurent GJ. Collagen turnover and its regulation in the normal hypertrophying heart. Eur Heart J 1995; 16: 38-44. https://doi.org/10.1093/eurheartj/16.suppl_C.38

20. Susanne W.M. van den Borne, Isobe S, Verjans JW, Petrov A, Lovhaug D, Li P, Zandbergen HR, Ni Y, Frederik P, Zhou J. et al. Molecular imaging of interstitial alterations in remodelling 
myocardium after myocardial infarction. JACC 2008; 52 (24): 2017-2028.

https://doi.org/10.1016/j.jacc.2008.07.067

21. Maisch B. Autoreactivity to the cardiac myocyte, connective tissue and the extracellular matrix in heart disease and postcardiac injury. Springer Seminars in Immunopathology 1989; 11: $369-95$.

https://doi.org/10.1007/BF00201877

22. Fedak PWM, Verma S, Weisel RD. Cardiac remodelling and failure. From molecules to man (Part II). Cardiovasc Pathol 2005; 14: 49-60.

https://doi.org/10.1016/j.carpath.2005.01.005

23. Jensen LT, Host NB. Collagen scaffold for repair or execution. Cardiovasc Res 1997; 33: 535-39. https://doi.org/10.1016/S0008-6363(96)00247-7

24. Kapelko VI. Extracellular matrix alterations in cardiomyopathy: The possible crucial role in the dilative form. Exp Clin Cardiol 2001; 6(1): 41-49.

25. Verjans JW, Lovhaug D, Narula N, Petrov AD, Indrevoll B, Bjurgert E, Krasieva TB, Petersen LB, Kindberg GM, Solbakken $\mathrm{M}$. et al. Noninvasive imaging of angiotensin receptors after myocardial infarction: JACC Cardiovascular imaging 2008; 1(3): 354-62.

https://doi.org/10.1016/j.jcmg.2007.11.007

26. Bujak M, Frangogiannis NG. The role of TGF signalling in myocardial infarction and cardiac remodelling: Cardiovascular Res 2007; 74 (2): 184-195. https://doi.org/10.1016/j.cardiores.2006.10.002

27. Gonzalez A, Lopez B, Querejeta R, Diez J. Regulation of myocardial fibrillar collagen by angiotensin II. A role in hypertensive heart disease? J Mol Cell Cardiol 2002; 34: 1585-1593. https://doi.org/10.1006/jmcc.2002.2081

28. Vantrimpont P, Rouleau JL, Ciampi A, Harel F, de Champlain J, Bichet D, Moyé LA, Pfeffer M. Two-year course and significance of neurohumoral activation in the Survival and Ventricular Enlargement (SAVE) study. Eur Heart J 1998; 19 (10): 1552-63. https://doi.org/10.1053/euhj.1998.1093

29. Anversa P, Olivetti G, Capasso JM. Cellular basis of ventricular remodeling after myocardial infarction. Am J Cardiol 1991; 18:68(14) 7D-16D.

30. Nahrendorf M, Sosnovik DE, French BA, Swirski FK, Bengel F, Sadeghi MM, Lindner JR, Wu JC, Kraitchman DL, Fayad ZA, Sinusas AJ. Multimodality cardiovascular molecular imaging, Part II. Circ Cardiovasc Imaging 2009; 2(1): 56-70. https://doi.org/10.1161/CIRCIMAGING.108.839092

31. Heymans S, Hirsch E, Anker SD, Aukrust P, Balligand JL,Cohen-Tervaert JW, Drexler H, Filippatos G, Felix SB, Gullestad L. et al. Inflammation as a therapeutic target in heart failure? A scientific statement from the translational Research Committee of the Heart Failure Association of the European Society of Cardiology. Eur J Heart Fail 11(2): 119-29, 2009. https://doi.org/10.1093/eurjhf/hfn043

32. Bristow M.R: $\beta$-adrenergic receptor blockade in chronic heart failure. Circulation 2000; 101(5), 558-69.

https://doi.org/10.1161/01.CIR.101.5.558

33. Ferrari R, Agnoletti L, Comini L, Gaia G, Bachetti T, Cargnoni A, Ceconi C, Curello S, Visioli O. Oxidative stress during myocardial ischemia and heart failure. Eur Heart J 1998; 19 (suppl B): S138-41.

34. Mudd JO, Kass DA. Tackling heart failure in the twenty first century. Nature 2008; 451(7181): 919-28.

https://doi.org/10.1038/nature06798

35. Lindsey ML, Goshorn DK, Squires CE, Escobar GP, Hendrick JW, Mingoia JT, Sweterlitsch SE, Spinale FG. Age-dependent changes in myocardial matrix metalloproteinase / tissue inhibitor of metalloproteinase profiles and fibroblast function. Cardiovasc Res 2005; 66(2): 410-9.

https://doi.org/10.1016/j.cardiores.2004.11.029

36. Weber KT. Targeting pathological remodeling. Concepts of cardio protection and reparation. Circulation 2000; 102: 1342-5. https://doi.org/10.1161/01.CIR.102.12.1342

37. Burlew BS, Weber KT. Connective tissue and the heart. Cardiol Clin 18: 435-42, 2000. https://doi.org/10.1016/S0733-8651(05)70154-5

38. Burgess WL, McCrea JC, Hedrick HL. Age-associated changes in cardiac matrix and integrins. Mesh Ageing Dev 2001; 122(15): 1739-56. https://doi.org/10.1016/S0047-6374(01)00296-2

39. Debessa CRG, Maifrino LBM, De Souza RR. Age related changes of the collagen network of the human heart. Mech Ageing Dev 2001; 122(10): 1049-58. https://doi.org/10.1016/S0047-6374(01)00238-X

40. Knöll R, Iaccarino G, Tarone G, Hilfiker-Kleiner D, Bauersachs J, Leite-Moreira AF, Sugden PH, Balligand JL. Towards a re-definition of 'cardiac hypertrophy' through a rational characterization of left ventricular phenotypes: a position paper of the Working Group'myocardial Function' of the ESC. Europen J of Heart Fail 2011; 13(8):811-9.

https://doi.org/10.1093/eurjhf/hfr071

41. Weinberg BA, Bealer BK. The world of caffeine: the science and culture of the world's most popular drug. New York: Routledge, Bulletin of history of Medicine 2003; 77(1): 217-218. https://doi.org/10.1353/bhm.2003.0012

42. Savoca MR, MacKey L, Evans CD, Wilson M, Ludvig DA, Harshfield GA. Association of ambulatory blood pressure and dietary caffeine in adolescents. Am J of Hypertension 2005; 18(1): 116-120.

https://doi.org/10.1016/j.amjhyper.2004.08.011

43. Rottlaender D, Motloch LJ, Reda S, Larbig R, Hoppe UC. Cardiac arrest due to long QT syndrome associated with excessive consumption of energy drinks. Int J of Cardiol 2012; 158(3): $51-2$. 
https://doi.org/10.1016/j.ijcard.2011.10.017

44. Loria CM, Mussolino ME. Usual sodium intakes compared with current dietary guidelines, Centers for Disease Control and Prevention, Morbidity and Mortality Weekly Report 2011; 60, (41), 1413-1417.

45. Seifert SM, Schaechter JL, Hershorin EK. Health effects of energy drinks on children, adolescents, and young adults. Pediatrics 2011; 127(3): 511-28.

https://doi.org/10.1542/peds.2009-3592

46. Reissig CJ, Strain EC, Griffiths RR. Caffeinated energy drinks; a growing problem. Journal Drug and Alcohol Dependence 2009; 99 (1-3), 1-10.

https://doi.org/10.1016/j.drugalcdep.2008.08.001

47. Berger AJ, Alford K. Cardiac arrest in a young man following excess consumption of caffeinated "energy drinks", MJA 2009; 190(1): 41-43.

48. Wang J, Chen H, Seth A, McCulloch. Mechanical force regulation of myofibroblast differentiation in cardiac fibroblasts. Am J Physiol Heart Circ Physiol 2003; 285(5):1871-1881. https://doi.org/10.1152/ajpheart.00387.2003

49. Matsubara LS, Matsubara BB, Okoshi MP, Cicogna AC, Janicki JS. Alterations in myocardial collagen content affect rat papillary muscle function. Am J Physiol Heart Circ. Physiol 2000; 279:1534-9.

50. Sharpe N. Cardiac remodelling in coronary artery disease. Am J Cardiol 2004; 93: 17-20.

https://doi.org/10.1016/j.amjcard.2004.01.002

51. Ballard SL, Wellborn-Kim JJ, Clauson KA. Effects of commercial energy drink consumption on athletic performance and body composition. Phys Sportsmed 2010; 38(1): 107-17. https://doi.org/10.3810/psm.2010.04.1768

52. Villarreal FJ, Kim NN. Regulation of myocardial extracellular matrix components by mechanical and chemical growth factors. Cardiovasc Pathol 1998; 7: 145-51. https://doi.org/10.1016/S1054-8807(97)00122-1

53. Sarkar S, Vellaichamy E, Young D, Sen S. Influence of cytokines and growth factors in ANG II - mediated collagen upregulation by fibroblasts in rats: role of myocytes. Am J Physiol Heart Circ. Physiol 2004; 287(1): $107-117$. https://doi.org/10.1152/ajpheart.00763.2003

54. Armulik A, Abramsson A, Betsholtz C. Endothelial/pericite interactions. Circ Res 2005; 97:512-523.

https://doi.org/10.1161/01.RES.0000182903.16652.d7

\section{JŪROS KIAULYČIUU MIOKARDO REAKCIJA I ENERGINIUS GĖRIMUS: STRUKTŪROS POKYČIAI}

A. Gružienė, L. Malcienè, S. Kerzienė, D. Skaudickas, G. Vaitiekaitis, G. Pečiulytė

Raktažodžiai: energiniai gèrimai, miokardo kolageno tinklas, remodeliacija, morfometrinis tyrimas.

Santrauka

Darbo tikslas: ịvertinti trumpaplaukių jūros kiaulyčių miokardo pokyčius, kurie atsiranda po 60 dienų kiekvieną dieną trunkančių energinių gèrimų vartojimo.

Eksperimentus atlikome su 11 vyriškos lyties 2 mènesių $220 \pm 0.2$ g trumpaplaukėmis jūros kiaulytėmis. Kontrolinèje grupèje buvo 5 trumpaplaukès jūros kiaulytès, o tiriamujų grupejje 6. Tiriamųjų grupès trumpaplaukès jūros kiaulytès kasdien buvo girdomos energiniais gèrimais po $4 \mathrm{ml}$ kartą per dieną. Po 60 dienų trukusio eksperimento, trumpaplaukių jūros kaiulyčių kairiojo skilvelio intersticiumo kolageno tinklo struktūras kiekybiškai vertinome automatine vaizdo analizès sistema, sujungta su Olympus BXx51mikroskopu. Vertinome naudodami Image-Pro Plus 5.1 analizès sistemą. Nustatėme kairiojo skilvelio miokardo intersticiumo fibrilinio kolageno tūrị, perimetrą ir atskirų skaidulų skaičių regèjimo lauke. Iš viso ịvertinome kontrolinès grupès 100 ir tiriamųju grupès 120 regèjimo laukų. Statistinè analizè buvo atlikta statistiniu paketu SPSS Statistics 20 ir skaičiuokle Excel. Histomorfometriniams parametrams palyginti tarp dviejų grupių naudojome dispersinès analizès (ANOVA) dviejų faktorių metodą.

Nustatème tarp kontrolinès ir tiriamųjų grupių iki $1 \%$ parametrų skirtumą ir $50 \%$ individo įtaką $(\mathrm{p}<0.05)$. Tiriamųjų grupejje daug didesné požymių variacija nei kontrolinèje grupejje. Tiriamųjų grupès didžiausios vidutinès fibrilinio kolageno tūrio, perimetro ir atskirų skaidulų skaičių regèjimo lauke reikšmės 1,2 karto didesnès nei kontrolinès grupès.

Kartotinis energinių gėrimų vartojimas veikia kaip išorinis veiksnys, stimuliuojantis adaptacinius remodeliavimosi procesus. Atsiradę tiriamujų grupejje kairiojo skilvelio fibrilinio kolageno kiekybiniai struktūros pokyčiai yra reakcija ị stresinị veiksmą. Nesubalansuotas fibrilinio kolageno persitvarkymas gali lemti neadekvačią remodeliaciją ir tapti patogenezès priežastimi.

Adresas susirašinėti: darijusskaudickas@gmail.com

Gauta 2017-10-12 